\title{
TWO QUALITY EVOLUTIONS: INDUSTRY VS. HEALTH CARE
}

Paper explains evolution of Global Quality Management Theory through changes of different quality management approaches in time and compares it to the evolution of Quality Management in Healthcare. Authors relied on already existing information and data sources published in scientific journals to define evolution paths and conduct their comparison to identify gaps and recommend improvements in Healthcare Quality Management. Additionally, four major activities that could improve healthcare quality management emerged from analysis, such as: mechanism for constant and systematic tracing errors, managing quality of supportive processes, control of outsource organizations and application of IT for quality assurance.

Keywords: Quality management, evolution, Health Care, industry, comparative analysis

* PhD, Aleksandra Živaljević, Assistant Professor at Faculty of Business Studies, „John Naisbitt” University, Belgrade, Serbia, azivaljevic@nezbit.edu.rs

** PhD, Dragana Trifunović, Assistant professor at Faculty of Business Studies, „John Naisbitt” University, Belgrade, Serbia, dtrifunovic@nezbit.edu.rs,

*** Ms, Biljana Pejović, Teaching assistant at Faculty of Business Studies, „John Naisbitt” University, Belgrade, Serbia, bpejovic@nezbit.edu.rs, 


\section{INTRODUCTION}

Healthcare system is an integral part of every society and it is considered to be an important indicator for country's level of development. The development level of a health care system is in direct correlation with the development level of the belonging country. On the one side, the quality of the health care system and health care services depend on the financial resources invested in health care, as a percentage of country's GDP. On the other side, the life quality of every citizen depends on the quality of the health care system. Therefore, the first aim of this system is to improve the quality of services and health of people in their daily life ${ }^{1}$.

Quality management in health care organizations evolved relatively independently from the development of the quality management theory ${ }^{2}$. One of the reasons for independent quality evolution could be the perception that health care differs from other hazardous industries in important ways ${ }^{3}$. Other reasons could be found in affiliation of those who contributed to healthcare quality management theory, while most of them were experts in medical sciences, but lacked in formal organizational and management knowledge, therefore neglecting similarities between healthcare and other industries, which resulted in neglecting existing achievements of the quality management theory.

Studies on the results of the implementation of quality management theory achievements testify that application of proposed models, principles and knowledge in industry, enables significant costs reduction ${ }^{4}$, performance improvement through productivity and effectiveness ${ }^{5}$, an increase in customer satisfaction ${ }^{6}$ and elimination of noncon-

Salimifard, K., Zanjirani, D.M., Keshtkar, L. (2014): “Using simulation to improve hospital resource management", Megatrend Review, 11 (3), 229-238.

2 Huycke, L.R., All, A.C. (2000): "Quality in health care and ethical principles", Journal of Advanced Nursing, 32(3), 562-571.

3 Wears, R. L., Hunte, G. S. (2014): “Seeing patient safety 'Like a State”, Safety Science, 67, 50-57

4 See: Seth, D., Tripathi, D. (2008): "Impact of Japanese Quality and Maintenance Management Solutions (TQM and TPM) on Business Performance: An Assessment for Indian Manufacturing Industry", 377-389, in: Mohanty, R.P. (ed.): Quality Management Practices, Excel Books, New Delhi; Jain, D. R., Mishra, V. (2009): “Total Quality Management: An Empirical Study on Employee's Perspective”, 248-260, in: Dhar, S., Dhar, U., Jain, R. K., Parashar S. (eds.): Value Based Management For Organizational Excellence, Indian Society for Training and Development, New Delhi; Ardianto, Y. T., Natsir, M. (2014): "Hybrid Strategies Study: Total Quality Management Practices and Supply Chain Management as a New Antesenden to Improve the Performance of Manufacturing in East Java", European Journal of Business and Management, 6(30), 1-10.

5 See: Seth and Tripathi, 2008; Heras-Saizarbitoria, I., Boiral, O. (2013): "ISO 9001 and ISO 14001: Towards a Research Agenda on Management System Standards", International Journal of Management Reviews, 15(1), 47-65; Douglas, A., Glen, D. (2000): "Integrated management systems in small and medium enterprises”, Total Quality Management, 11, 686-690; Jang, W., Lin, C. (2008): “An integrated framework for ISO 9000 motivation, depth of ISO implementation and firm performance. The case of Taiwan", Journal of Manufacturing Technology Management, 19, 194-216.

6 See: Vouzas, F., Psychogios, A. G. (2007): “Assessing managers' awareness of TQM", The TQM Magazine, 19(1), 62-75; Yang, C. C. (2006): “The impact of human resource management practices on the implementation of total quality management: an empirical study on high-tech firms", The TQM 
formities or low quality of products and services ${ }^{7}$. At the other side, there are numerous discussions on quality results and effectiveness of applied measures and concepts in health care, whereas problems of high $\operatorname{costs}^{8}$ poor service ${ }^{9}$ and too frequent patients' disappointing outcomes ${ }^{10}$ are constantly stressed in reports, studies and manuscripts. Poor quality in other industries has no fatal impact on human's life, and in most of the cases it can be reparable, but poor quality of health care can make lethal consequences immediately or after a certain time. Therefore, it could be concluded that achieving quality in health care is one of the most important goals, and that all efforts and obtained scientific knowledge should be aimed at achieving total quality in health care.

However, today's results in certain area of scientific discipline represent a significant scientific heritage, which a scientific discipline has passed from the moment of its birth until today. The evolution path of a scientific discipline in some areas can be seen as a series of interdependent steps, while previous finding influences next research, and therefore the future findings as well. To understand whether there is a difference in the perception of health care quality and perception of quality in the industry, as well as if whether there were an actual difference, then in order to understand why such difference would exists, we would have to study evolution of quality management in both areas.

Magazine, 18(2), 162-173; Mersha, T., Sriram, V., Herron, L. (2009): “The impact of TQM implementation in a human service agency", International Journal of Productivity and Quality Management, 4(1), 1-19.

7 Martínez-Lorente, A. R., Martínez-Costa, M. (2004): "ISO 9000 and TQM: substitutes or complementaries?: An empirical study in industrial companies”, International Journal of Quality and Reliability Management, 21 (3), 260-276; Alic, M., Rusjan, B. (2010): "Contribution of the ISO 9001 internal audit to business performance", International Journal of Quality and Reliability Management, 27(8), 916-937.

$8 \quad$ See: Cutler, D. (2014): The Quality Cure: How Focusing on Health Care Quality Can Save Your Life and Lower Spending Too, University of California Press. (Volume 9); Cabin, W., et. al. (2014): "ForProfit Medicare Home Health Agencies' Costs Appear Higher and Quality Appears Lower Compared To Nonprofit Agencies", Health Affairs, 33(8), 1460-1465; Turan, A. H., Palvia, P. C. (2014): "Critical information technology issues in Turkish healthcare", Information and Management, 51(1), 57-68; Parekh, A. K., Kronick, R., Tavenner, M. (2014): “Optimizing health for persons with multiple chronic conditions", JAMA, 312(12), 1199-1200;

9 Turan, A. H., Palvia, P. C., 57-68; Amarasingham, R. et. al. (2014): "Implementing Electronic Health Care Predictive Analytics: Considerations and Challenges”, Health Affairs, 33(7), 1148-1154; Attanasio, O., Oppedisano, V., Vera-Hernández, M. (2014): "Should Cash Transfers Be Conditional? Conditionality, Preventive Care, and Health Outcomes", American Economic Journal: Applied Economics.

10 George, V. M., Shocksnider, J. (2014): "Leaders: Are You Ready for Change? The Clinical Nurse as Care Coordinator in the New Health Care System", Nursing Administration Quarterly, 38(1), 78-85; Main, D. S., et. al. (2007) "Relationship of processes and structures of care in general surgery to postoperative outcomes: a qualitative analysis", Journal of the American College of Surgeons, 204(6), $1147-1156$. 


\section{METHODOLOGY OF RESEARCH}

The aim of this manuscript is to explain evolution of Global Quality Management Theory through changes of different quality management approaches and to compare it to evolution of Quality Management in Health Care, both timely based. Additionally, comparison should result in enabling identification of the gaps and recommendations for future research and improvements in Health Care Quality Management.

In order to pursue the aim of this research the authors relied on already existing information and data sources published in scientific journals. The research was divided in three phases of research: research on evolution of Global Quality Management Theory, research on evolution of Quality Management in Health Care and comparative analyses of both obtained researches.

For the purpose of the first research phase, EBSCO scientific base was used to access scientific journals which contained useful data for the research. Period in which reviewed and analysed scientific journals were published dated from 1900-2014, although the history of scientific management begins with the life and career of Frederick Winslow Taylor ${ }^{11}$. Key words "quality evolution“ or "quality history" or "quality movement" in the title of manuscripts were used as a criterion of search, which resulted in 217 manuscripts. Abstracts of all manuscripts were analysed while only 37 of them were useful for research on Global Quality Management Theory evolution. According to the analyses of useful manuscripts, phases in Global Quality Management Theory evolution were identified, timely ordered and specified through their characteristics.

For the second phase of research EBSCO base together with Free Medical Journals base were used to obtained data referred to the evolution of quality management in health care. This time key words were "health care" in the text of manuscript and "quality" and "evolution" in the title of manuscript, which resulted in 334 manuscripts, but only 14 of them contained useful information. All useful manuscripts were analysed, stages in Health Care Quality Management evolution were identified and timely ordered, separately from the results of previous research phase and each stage of evolution was specified through their characteristics.

In the third phase of research, obtained results of the second research phase were compared to obtained results of the first research phase, gaps were identified and recommendations for future evolution path were defined.

Kreis, S. (1995): "Early experiements in British scientific management: the Health of Munitions Workers' Committee, 1915-1920”, Journal of Management History, 1(2), 65-78. 


\section{EVOLUTION OF GLOBAL QUALITY MANAGEMENT THEORY}

Some authors argue that there were four main stages in Global Quality Management Theory evolution in the last century ${ }^{12}$. Some other authors insist on five stages in quality movement ${ }^{13}$ also in the last century, arguing that last phase begun in late $90 \mathrm{~s}$ and is still on-going. The authors of this manuscript have opted to the evolution of the Global Quality Management Theory based on five phases in the last century, aiming to better comprehend the difference in approaches and methodologies for quality achievement. Therefore, the most suitable manuscript for tracing changes in evolution of the Global Quality Management Theory was written by Raho and Mears and was published in 1997. Research and analysis of happenings in Global Management Theory pointed to the adoption of new concepts and methods in 21st century. Therefore, the authors argue that evolution of the quality management theory has developed through six main phases, constantly using experience of industry. Each phase of quality management theory evolution characterise application of methods or approaches which were motivated by an efforts for assuring quality of particular entity, i.e. a part of an organization or its output. Also, in each phase the quality was understood in different ways, and attention was directed to different entities of an organization to be managed for quality achievement, as well as the different parts of an organization were considered as responsible for the quality of stressed entity. Phase characteristics of the Global Quality Management Theory evolution are explained in Table 1.

The switch from previous phase to the next one was not characterized by reengineering, which assumes abandoning everything that has marked the previous phase. The evolution of quality management theory is rather proposing a growth of knowledge in the field of the quality management, based on adding new concepts to the concepts that showed results in previous phases. It means that inspection of products and detection of nonconformities were never abandoned, as methods for quality achievement ${ }^{14}$. Moreover, nonconformities are not looked at only as defective products, but also as mistakes and errors in all processes of a business system. Analyses of causes that led to nonconformities enable system's corrective actions that are important part of continuous quality improvement.

12 See: Zhao, X., Yeung, A. C., Lee, T. S. (2004): "Quality management and organizational context in selected service industries of China", Journal of Operations Management, 22(6), 575-587; Prickett, T. W., Rapley, C. W. (2001): "Quality costing: a study of manufacturing organizations. Part 2: main survey”, Total Quality Management, 12(2), 211-222; Kuei, C. H., Madu, C. N. (2003): "Customercentric six sigma quality and reliability management", International Journal of Quality and Reliability Management, 20(8), 954-964.

13 Raho, L., Mears, P. (1997): "Quality system chaining: The next link in the evolution of quality", Business Horizons, 40(5), 65-73; Salah, S., Carretero, J. A., Rahim, A. (2009): "Six Sigma and Total Quality Management (TQM similarities, differences and relationship", International Journal of Six Sigma and Competitive Advantage, 5(3), 237-250; Ivanovic, M. D., Majstorovic, V. D. (2006): "Model developed for the assessment of quality management level in manufacturing systems", The TQM Magazine, 18(4), 410-423.

14 Berlin, C. (1994): "Implementation of the total quality management concept within space business", Total Quality Management, 5(4), 123-137. 
Until the early 1980s the manufacturing sector was centre stage in the quality debate $^{15}$. However, from the mid-1980s quality management theory started to pay a greater interest to issues of customer services while nature of service organizations raised methodological and conceptual issues in relation to the transfer of quality management practices developed in manufacturing ${ }^{16}$.

Through time, quality management theory developed concepts and models that are applicable on any type of industry. All concepts and models are based on standards, regulations or recommendations that can be used as guidelines for designing a specific model for a specific organization ${ }^{17}$. However, the major breakthrough was made in 21 st century by the appreciation of other scientific disciplines achievements and the development of the Global Quality Management Theory through the synergy of IT technology, cybernetics, theory of organization and management in all disciplines.

\section{EVOLUTION OF QUALITY MANAGEMENT IN HEALTH CARE}

Evolution of quality management in health care was caused by efforts to reduce high mortality rate of wounded soldiers in the Crimean War ${ }^{18}$ which led to establishing standards for nursing care and efforts to manage conditions which would enable desired results of care. Until than up to nowadays, quality in health care has gone a long way during which the theory of management and theory of organization were slowly creating an impact on contemporary understanding of quality in health care.

The beginnings were based on the attempts to control the isolated parts of the health care business system, which was not seen at that time as a system at all, until Donabedian proposed his model. Although achievements in maintenance of human health have been the main goal of the health care system always, the quality has been understood in different manner in the different periods of evolution. The change in perception of quality of health care was heavily influenced by the development of medical science. In fact, in the beginnings of evolution of quality management in health care, the medical knowledge was modest compared to today's knowledge opus; the medical equipment was rather primitive compared to today's modern medical devices and the pharmaceutical industry was still in its infancy. Therefore, the desired results could not be achieved anyway; however, the question of whether results would be better in past if

15 Yong, J., Wilkinson, A. (2002): “The long and winding road: The evolution of quality management”, Total Quality Management, 13(1), 101-121

16 Lewis, B. (1999): “Managing service quality” 181-197, in: Dale, B. (Ed.) Managing Quality, Blackwell, Oxford.

17 Wagner, C., et. al. (2006): “The implementation of quality management systems in hospitals: A comparison between three countries", BMC Health Services Research, 6(1), 50- 61.

18 Bull, M. J. (1997): “Lessons from the past: vision for the future of quality care. Improving Quality", 3-16, in: Maisenheimer, C. G. (ed.): A Guide to Effective Programs, Gaithersburg, Md.: Aspen Publishers, Massachusetts (2nd edition) 
than knowledge of the Global Quality Management Theory was applied in health care quality attempts is arising.

Authors of manuscript recognized five stages of the quality management evolution in health care. Those stages along with their characteristics are given in Table 2.

Every next stage in evolution did not bring radical redesign destroying all the previous approaches. The evolution of quality management in health care was also contributing to the upgrade of knowledge base, where in certain periods of time some of the approaches and methods dominated the stage by incorporating previous accomplishments. Influence of the Governments and role of the World Health Organization in quality management of each health care institution should not be neglected, while health care is being, in contrast to industry, the area of importance for each country and an integral part of social and political programs of every Government's policy.

\section{ANALYSIS AND DISCUSSION}

According to comparative analysis shown in Table 3, it is obvious that the differences between evolution paths of health care quality management and global quality management theory actually exist. As authors claimed in introduction part, that quality management accomplished better results in industry than in health care, first question that arises is why there is a difference between those two evolution paths? If the cause for these differences between these two evolution paths does not lay in substantial differences between industry and health care, which would disable implementation of industry methods in health care, than the second question is what health care can learn from quality management theory to avoid unwanted outcomes?

As it is proven that health care institutions can be seen as a business system ${ }^{19}$ than no obstacle to the use of industry achievements in improving the quality of health care institutions could be identified. However, the cause of differences in evolution paths could be found in formal education of their contributors while doyens to health care quality management evolutions were not familiar with the science of organization or management science. Edwin Chadwick was a lawyer by training ${ }^{20}$, Florence Nightingale was a nurse ${ }^{21}$, Abraham Flexner was an educator ${ }^{22}$, Avedis Donabedian was a physi$\operatorname{cian}^{23}$. Therefore, the basis for analysing and conclusions about the ways for improvements in health care institutions in that time could not be the same as the conclusions

\footnotetext{
19 Živaljević, A., Mitrović, Ž., Petković, M. (2013): “Conceptual and mathematical model for quality improvement in health care“, The Service Industries Journal, 33(5), 516-541.

20 Hébert, R. F. (1977): "Edwin Chadwick and the economics of crime", Economic Inquiry, 15(4), 539550.

21 Cohen, I. B. (1984): “Florence Nightingale”, Scientific American, 250(3), 128-137.

22 Drake, R. L. (2014): "A retrospective and prospective look at medical education in the United States: Trends shaping anatomical sciences education", Journal of anatomy, 224(3), 256-260.

23 Mullan, F. (2001): "A founder of quality assessment encounters a troubled system firsthand", Health Affairs, 20(1), 137-141.
} 
of their contemporaries who have shaped the evolution of global quality management theory through researches and studies in the industry. Comparative analyse showed that health care quality management failed to apply:

- Mechanism for constant systematic identification of errors and its analysis in order to eliminate its cause (concluded from last row in table 3: identifying errors; identifying critical activities in processes; setting control points; using recorded data on errors to prevent them in future)

- Applying system and process approach on whole health care institution, not only on clinical parts (concluded from last row in table 3: control of supportive processes in certification and accreditation; controlling all elements of system; not just stuff, clinical processes and equipment; applying TQM principles on whole organization, not just clinical stuff and processes; using quality tools, methods for process and costs optimization and Six sigma for any improvement; monitoring and measuring quality parameters of key and critical processes, not only of medical methods, departments or facility.)

- Controlling outsource organization.

- Using IT for quality achievement and for service delivery

\subsection{Systematic identification of errors}

Identification of nonconformities was the base to the first phase of evolution in industry and that method is still present in practice and theory, nowadays. However, it has spread from production process on whole business system by monitoring and measuring key processes, conducting internal audits and analysing customer complains. All nonconformities are analysed to identify their causes and to eliminate them by corrective actions. It is common mechanism for quality improvement in industry, which cannot be applied in health care if errors are not traced.

Serious errors in health care are reported, but methods that would allow detection of minor errors in the whole system of health care facility and which would enable health care facility to react before something serious happens are not implemented. Authors believe that major reasons for absenteeism of systematic tracing errors could be:

- Tracking errors in health care institutions is not an easy process and requires additional engagement of employees and their conscientiousness, honesty and self-criticism.

- Errors which are caused by lack of medical knowledge can initiate serious consequences for employee's career, while those errors caused by malicious intentions can open judicial processes in which the doctor can face a jail and exclusion from society

- Patient complain only when they have suffered serious consequences of errors but they usually do not recognize errors if there were no serious consequences 
- Internal audits are conducted in clinical processes while supportive processes are neglected even if it is known that supportive processes influence results of health care institution ${ }^{24}$

- Internal audits are conducted by experts in medicine who are usually not familiar in audit methodology $y^{25}$.

\subsection{System and process approach}

Quality management theory recognized service or product quality dependence on process and system performance. Therefore, most models for quality management are based on process and system approach, which respect all of the important processes, which are supportive processes and production processes, in quality achievement. In health care institutions, supportive processes are less present in percentage compared to clinical processes and in the development of health care institution are often neglected, i.e. considered as not important although their quality significantly affects the quality of clinical processes. An example of the supportive process impact on clinical process can be found in the process of procurement which, if not optimized, can give bad or insufficient inputs or resources to clinical processes: bad or insufficient medical supplies, defective or insufficient medical devices and under competent or insufficient medical personnel, and thus it would jeopardize the quality of clinical processes and the quality of their outcomes. At the first glance supportive processes seem less important for achieving the quality of health services, but they need to be improved and controlled together with clinical processes. As one of the methods of achieving quality of clinical processes is protocol or procedure, the same method should be applied in quality management of supportive processes. If measuring and monitoring quality parameters of clinical processes or conducting internal audits on them, why not doing the same in the case of important supportive processes? While there is no shortage of written protocols in healthcare, they are not as effective as they could be in helping healthcare workers to avoid errors ${ }^{26}$. Reasons of poor quality in health care could be found in barriers for implementation ${ }^{27}$, as well as in understanding and transforming guidelines into the specific model, which does not cover all elements of healthcare organization systems in most of the cases ${ }^{28}$.

24 Naumova, N. A., Kharisova, F. I. (2014): "Effective Internal Audit Service Organisation in Health Clinics", Mediterranean Journal of Social Sciences, 5(24), 170-179.

25 Naumova, N. A., Kharisova, F. I., 170-179.

26 Porto, G. G. (2001): "Safety by design: Ten lessons from human factors research", Journal of Healthcare Risk Management, 21(3), 43-50.

27 Ferlie, E.B., Shortell, S.M. (2001): "Improving the quality of health care in the United Kingdom and the United States: A framework for change”, Milbank Quarterly, 79(2), 281 -316.

28 Živaljević, A., Mitrović, Ž., Petković, M., 516-541. 


\subsection{Controlling outsource organization}

Often, more than one healthcare institution participates in the process of delivering healthcare services ${ }^{29}$ and all of them influence final outcome. Therefore, it is important that all of those manage their quality constantly and systematically. Much like a military control of outsource by conducting audits, in the case of health care institution it would require stuff trained in audit methodology, or a partnership with specialized companies tailored for auditing process. However, such effort would decrease possibilities of misdiagnosis or bad treatment and the initial additional financial investments in additional activities of audits would lead to a reduction of costs in the future period.

\subsection{Using IT for quality achievement and for service delivery}

There are special softwares designed to manage quality in industry. Some of them control production process enabling people-less activity conduction, some of them advise employees in their working process (for example hotel's database on previous customers' needs), while some of them are designed to facilitate monitoring and measuring of quality parameters. Information technology is used predominantly for patient's electronic charts, and for data transfer from one health care unit to another. However, IT can replace people in routine clinical activities, this reducing human-error possibilities and accelerating activities. Also, indicators of possible errors occurrence, such as: diagnose change, too long treatments, complications in treatments, unusual symptoms developed during treatment could be monitored by contemporary and widely available IT.

${ }^{29}$ Živaljević, A., Mitrović, Ž., Petković, M., 516-541. 


\section{CONCLUSION}

In recent years, the increasing importance of quality management has promoted the implementation and diffusion of tools finalized to measure and to monitor the healthcare outcomes ${ }^{30}$. However, for essential quality improvements it is necessary to trace nonconformities, analyse them to find their root cause and to implement corrective actions. Quality is defined as a customer satisfaction ${ }^{31}$, while the first step for its accomplishment is to eliminate errors and it cannot be done without tracing them. As tracing errors requires additional time, efforts and financial investments IT could be used to minimize all of those.

Researches on TQM implementation in health care facilities suggests that the gains made in health care (as in other organisations) have not been as great as predicted ${ }^{32}$. A particular problem has been its aggressive rhetoric and its failure to engage the staff on whom the organisation relies ${ }^{33}$. Nowadays, it is common to educate employees in industry's quality management practice in order to incorporate them in quality improvement efforts by their participation, team work and self-assessment. However, providers in health care often lacked basic Qi knowledge or experience in instituting Qi programs ${ }^{34}$. There are clear messages from conducted studies that, where some progress has been made, the engagement of clinicians has been essential, as well as senior management commitment and persistence ${ }^{35}$. Therefore, health care employees' knowledge on global quality management theory accomplishments has to be improved. Also, it is needed to incorporate quality control of supportive processes and of outsource organizations in quality management efforts in health care.

Policy makers seek new ways to address continuing problems of variation in the quality of health care and dissatisfaction among patients, the public, and profession$\mathrm{als}^{36}$. Minimizing gaps between industry practices and health care practice, by adopting methods that gave desirable results in quality improvement, can improve quality in health care.

$30 \quad$ Foltran F, et. al. (2009): "Monitoring the performance of intensive care units using the variable lifeadjusted display: a simulation study to explore its applicability and efficiency", Journal of evaluation in clinical practice, 15(3), 506-513.

31 Gill, J. (2009): "Quality follows quality: add quality to the business and quality will multiply the profits”, The TQM Journal, 21(5), 530-539.

32 Locock, L. (2003): "Healthcare redesign: meaning, origins and application", Quality and Safety in Health Care, 12(1), 53-57.

33 Grint, K., Case, P. (1998): “The violent rhetoric of reengineering: management consultancy on the offensive", J Manag Stud, 35, 557-77.

34 Scanlon, D.P., et. al. (2012): “The Aligning forces for Quality initiative: Background and evolution from 2005 to 2012", Am J Manag Care, 18(6), 115-125.

35 Locock, L., 53-57.

36 Locock, L., 53-57.

Vol. 13, No 1, 2016: 159-184 
Table 1. Evolution of the Global Quality Management Theory

\begin{tabular}{|c|c|c|c|}
\hline $\begin{array}{l}\text { Phase } \\
\text { and } \\
\text { period }\end{array}$ & $\begin{array}{c}\text { 1800-1930 } \\
\text { Inspection and Test }\end{array}$ & $\begin{array}{l}\text { 1930-1950 } \\
\text { Quality Control }\end{array}$ & $\begin{array}{c}\text { 1950-1980 } \\
\text { Quality Assurance }\end{array}$ \\
\hline Entity & Product & Production process & $\begin{array}{l}\text { Production and supportive } \\
\text { processes }\end{array}$ \\
\hline $\begin{array}{l}\text { Quality } \\
\text { understa- } \\
\text { nding }\end{array}$ & $\begin{array}{l}\text { Compliance of realized } \\
\text { product features with the } \\
\text { designed product features }\end{array}$ & $\begin{array}{l}\text { Compliance of realized } \\
\text { product features with the } \\
\text { designed product features } \\
\text { but with optimal costs of } \\
\text { production }\end{array}$ & $\begin{array}{l}\text { Compliance of realized } \\
\text { product features with the } \\
\text { designed product features } \\
\text { but with optimal costs of } \\
\text { important processes }\end{array}$ \\
\hline $\begin{array}{l}\text { Main } \\
\text { Goal }\end{array}$ & $\begin{array}{l}\text { Disabling defective product } \\
\text { appearance on market }\end{array}$ & $\begin{array}{l}\text { Decreasing occurrence } \\
\text { of defective products } \\
\text { and decrease costs of } \\
\text { productions }\end{array}$ & $\begin{array}{l}\text { Preventing occurrence of } \\
\text { nonconformities }\end{array}$ \\
\hline 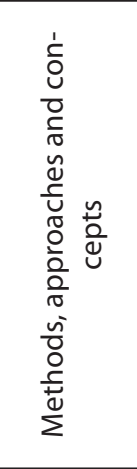 & $\begin{array}{l}\text { Product characteristics and } \\
\text { features were inspected } \\
\text { at the end of production } \\
\text { process. } \\
\text { Defect products were } \\
\text { repaired if possible, or } \\
\text { rejected if not reparable }\end{array}$ & $\begin{array}{l}\text { Control points were set } \\
\text { after critical activities to } \\
\text { inspect product quality. } \\
\text { Nonconformities were } \\
\text { recorded to use data in } \\
\text { control charts and statistical } \\
\text { methods to anticipate the } \\
\text { time of unwanted variations. } \\
\text { In identified time production } \\
\text { process was stopped and } \\
\text { causes of variations were } \\
\text { removed if possible. }\end{array}$ & $\begin{array}{l}\text { Flow charts and procedures } \\
\text { of processes important for } \\
\text { quality were used to direct } \\
\text { process. } \\
\text { Quality plan for each product } \\
\text { or service was etalon and } \\
\text { starting point. }\end{array}$ \\
\hline 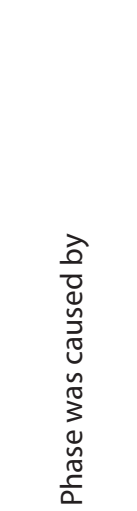 & $\begin{array}{l}\text { Taylor F. contributed by } \\
\text { introduction of normative } \\
\text { and inspection for } \\
\text { maximizing productivity and } \\
\text { eliminating poor quality of } \\
\text { products }\end{array}$ & $\begin{array}{l}\text { Shewhart W. contributed by } \\
\text { applying statistical methods } \\
\text { on production process in } \\
\text { order to detect the time of } \\
\text { defect occurrence at Bell } \\
\text { Laboratories in the early } \\
\text { 1920s and developed the } \\
\text { control chart in } 1924\end{array}$ & $\begin{array}{l}\text { Shewhart W. with Deming } \\
\text { E. introduced PDCA cycle in } \\
1950 . \\
\text { Juran J. contributed with } \\
\text { theory of quality costs in } \\
1951 .\end{array}$ \\
\hline
\end{tabular}


1980-1990

Strategic Quality

Management
1990-2000

Total Quality Management
From 2000 and further

Quality of Life and Sustainability

Business system

All organizations in supply chain Society and all its parts

Satisfying customers' needs by products and services which are result of optimal process conduction in organization

Satisfying stakeholders' needs by outcomes which are result of optimal process conduction in supply chain

Satisfying customers' needs

Satisfying current and future needs of every person in society

\section{Satisfying stakeholders' needs}

\section{Enabling quality of life and environment}

\begin{abstract}
Strategic planning and SMART goal setting were starting points. QFD method was used to develop features of product or service in quality planning. The entire organization was mobilized to achieve quality. For any improvement quality tools, methods for process and costs optimization and Six sigma were used.
\end{abstract}

Implementation of revised ISO 9000

Implementation of integrated management systems implementation of Business Excellence models

\author{
Supply chain management \\ Sustainable development \\ Social Responsibility \\ TQM principles \\ System and process approach \\ Monitoring and measuring of \\ quality parameters of key and \\ critical processes \\ Information technology
}

\begin{tabular}{|c|c|c|}
\hline $\begin{array}{l}\text { Deming E. introduced, fourteen } \\
\text { points of management in } 1982\end{array}$ & $\begin{array}{l}\text { Deming E. introduced Theory of } \\
\text { profound knowledge in } 1993^{1}\end{array}$ & $\begin{array}{l}\text { Oliver K. introduced the term of } \\
\text { Supply chain management in }\end{array}$ \\
\hline Juran J. contributed with The & Industry started with & 1982 which Hines P. promoted \\
\hline Quality Trilogy in 1986 & implementation of the first & in $2004^{3}$ UN World Commission \\
\hline Feigenbaum A. developed & version of ISO 9000:94 series $^{2}$ & on the Environment and \\
\hline a concept of "Total Quality & Juran J. contributed with concept & Development set the basis for \\
\hline Control" in 1968. & of process triple role in 1988. & Sustainable development in \\
\hline $\begin{array}{l}\text { Ishikawa K. developed cause and } \\
\text { effect diagram in } 1970 .\end{array}$ & $\begin{array}{l}\text { Ishikawa K. emphases the } \\
\text { importance of internal customer }\end{array}$ & $\begin{array}{l}1987^{4} \text { Bowen gave definition of } \\
\text { social responsibility in his book }\end{array}$ \\
\hline $\begin{array}{l}\text { Six Sigma developed by } \\
\text { Motorola in } 1986\end{array}$ & $\begin{array}{l}\text { and implementation of quality } \\
\text { circles in } 1980 .\end{array}$ & $\begin{array}{l}\text { in } 1953 \text { whish UN Commission } \\
\text { promoted in } 2001^{5}\end{array}$ \\
\hline & $\begin{array}{l}\text { Taguchi G. introduced The } \\
\text { Taguchi Loss Function in late } \\
\text { 1980s and helped fuel the } \\
\text { continuous improvement } \\
\text { movement. }\end{array}$ & $\begin{array}{l}\text { New version of ISO } 9001: 2000 \\
\text { adopted TQM principles }{ }^{6} \text { and } \\
\text { promoted system approach, } \\
\text { process approach, monitoring } \\
\text { and measuring quality }\end{array}$ \\
\hline & $\begin{array}{l}\text { Shingo S. developed Zero Defect } \\
\text { concept in 1961, SMED in } 1970 \\
\text { and JIT in 1990. }\end{array}$ & $\begin{array}{l}\text { parameters of key processes } \\
\text { as well as the continual quality } \\
\text { improvement }{ }^{8} \text {. }\end{array}$ \\
\hline
\end{tabular}


Table 2. Evolution of the Health Care Quality Management

\begin{tabular}{|c|c|c|c|}
\hline 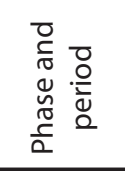 & $\begin{array}{c}1800-1950 \\
\text { Quality assurance } \\
\text { of in health care facilities conditions } \\
\text { and medical staff }\end{array}$ & $\begin{array}{l}1950-1970 \\
\text { Quality assurance of } \\
\text { structure of health care }\end{array}$ & $\begin{array}{l}\text { 1970-1980 } \\
\text { Quality assurance } \\
\text { of care processes }\end{array}$ \\
\hline Entity & Outcome & Structure elements & Process of care \\
\hline $\begin{array}{l}\text { Quality } \\
\text { under- } \\
\text { standng }\end{array}$ & Decrement of mortality rate & $\begin{array}{l}\text { Compliance of structure } \\
\text { elements and structure- } \\
\text { related standards }\end{array}$ & Meeting the standards \\
\hline $\begin{array}{l}\text { Main } \\
\text { Goal }\end{array}$ & Avoiding unwanted outcome & Improving structure & $\begin{array}{l}\text { Improving clinical } \\
\text { processes }\end{array}$ \\
\hline 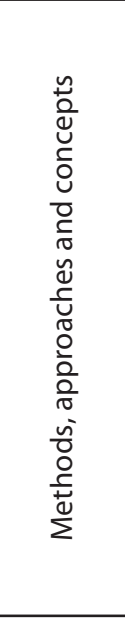 & $\begin{array}{l}\text { Awareness of the sanitary problems } \\
\text { associated with community } \\
\text { dwelling } s^{11} \text {. Organizing hospital } \\
\text { medical staffs }{ }^{12} \text {. Limiting staff } \\
\text { membership to well-educated, } \\
\text { competent, and licensed physicians } \\
\text { and surgeons }{ }^{13} \text {. Framing rules and } \\
\text { regulations to ensure regular staff } \\
\text { meetings and clinical review }{ }^{14} \text {. } \\
\text { Keeping medical records that } \\
\text { included the history, physical } \\
\text { examination, and laboratory results } \\
\text { of a patient }{ }^{15} \text { Establishing supervised } \\
\text { diagnostic and treatment facilities } \\
\text { such as clinical laboratories and } \\
\text { radiology departments }^{16} \text {. }\end{array}$ & $\begin{array}{l}\text { Concepts of accreditation } \\
\text { and certification entered } \\
\text { the quality equation }{ }^{17} \text {. } \\
\text { Continued to focus on } \\
\text { human and physical } \\
\text { resources }^{18} \text {. }\end{array}$ & $\begin{array}{l}\text { Introduction in the } \\
\text { clinical process-related } \\
\text { standards and guidelines. } \\
\text { Providers of health care } \\
\text { were then "judged" } \\
\text { on their compliance to } \\
\text { certain } \\
\text { explicit standards of care } \\
\text { and practice parameters } \\
\text { by their peers". }\end{array}$ \\
\hline 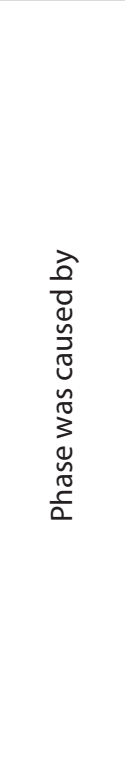 & $\begin{array}{l}\text { Dr Edwin Chadwick, published } \\
\text { a report in } 1842 \text { which vividly } \\
\text { described the unacceptable sanitary } \\
\text { conditions associated with urban } \\
\text { and rural communities in Britain at } \\
\text { that time }{ }^{29} \text {. In Britain, around } 1854, \\
\text { Florence Nightingale first noticed } \\
\text { the positive correlation between the } \\
\text { introduction of adequate nursing } \\
\text { care to wounded soldiers and the } \\
\text { decrease in the mortality rate among } \\
\text { this group. She introduced first } \\
\text { nursing care standards }{ }^{30} \\
\text { Abraham Flexner's reported on } \\
\text { survey results on situation in medical } \\
\text { schools and major hospitals in } 1910 \\
\text { to Karnage Foundatio }{ }^{31} \text {. American } \\
\text { College of Surgeons established its } \\
\text { Hospital Standardization Program in } \\
\text { 1917 }{ }^{32} \text {. }\end{array}$ & $\begin{array}{l}\text { Creation of the US } \\
\text { Joint Commission } \\
\text { on Accreditation of } \\
\text { Hospitals in 1951, } \\
\text { which was renamed } \\
\text { the Joint Commission } \\
\text { on Accreditation of } \\
\text { Healthcare Organizations } \\
\text { in } 1987^{33} \text { In } 1966 \text { Dr } \\
\text { Avedis Donabedian } \\
\text { introduced a model } \\
\text { of measuring quality } \\
\text { based on "simple system } \\
\text { theory" }\end{array}$ & $\begin{array}{l}\text { From the Joint } \\
\text { Commission on the } \\
\text { Accreditation of } \\
\text { Healthcare Organizations } \\
\text { accreditation model was } \\
\text { exported via Canada to } \\
\text { Australia in the } 1970 \text { s and } \\
\text { arrived in Europe in the } \\
1980 \mathrm{~s}^{35} \text {. First regional, } \\
\text { state or } \\
\text { provincial accreditation } \\
\text { agencies and bodies } \\
\text { were established all over } \\
\text { the world }{ }^{36} \text {. }\end{array}$ \\
\hline
\end{tabular}


$1980-2000$

Quality improvement
From 2000

Performance improvement

\begin{tabular}{l}
\hline Back to outcomes \\
Standardizing care will decrease chance of error \\
and improve control of patient care outcome
\end{tabular}

Performance which enhance and extend the life

Enhancing life expectancy, quality of life, diagnostic and treatment options, as well as the efficiency and cost effectiveness of the healthcare system $^{10}$

\section{Excellence of performance}

Institution measures its performance against a number of well-known and agreed-on measures (or indicators), and the results are published so that the consumer can compare this institution with ones similar to $\mathrm{it}^{24}$. Engaging highly educated and well informed consumer ${ }^{25}$. Certification, accreditation and licensure measurement and public reporting of the adoption and spread of effective Qi strategies to improve care ${ }^{26}$. Ensuring the equitable receipt of healthcare; and integration of alliance activities with payment reform initiatives ${ }^{27}$. Accreditation has spread across the world to become an established part of healthcare systems in over 70 countries and there is an associated international body ${ }^{28}$.

Synergy of medical and other science resulted in advanced, modern medical devices and medical technology for diagnosis and treatment. New quality dimensions have recently been introduced in the US by the prestigious Institute of Medicine in their 2001 report $^{39}$. These are: safety, timeliness, equity, effectiveness, efficiency, and patient centeredness ${ }^{40}$.

In 2006, Af4Q program works to improve healthcare by engaging patients in their care, publicly reporting the performance of physicians and hospitals, and improving the quality of care delivered in each community ${ }^{41}$. In 2002, SSM Health Care became the first health care organization in the USA to win the Malcolm Baldrige National Quality Award ${ }^{42}$. 
Table 3. Comparative analysis

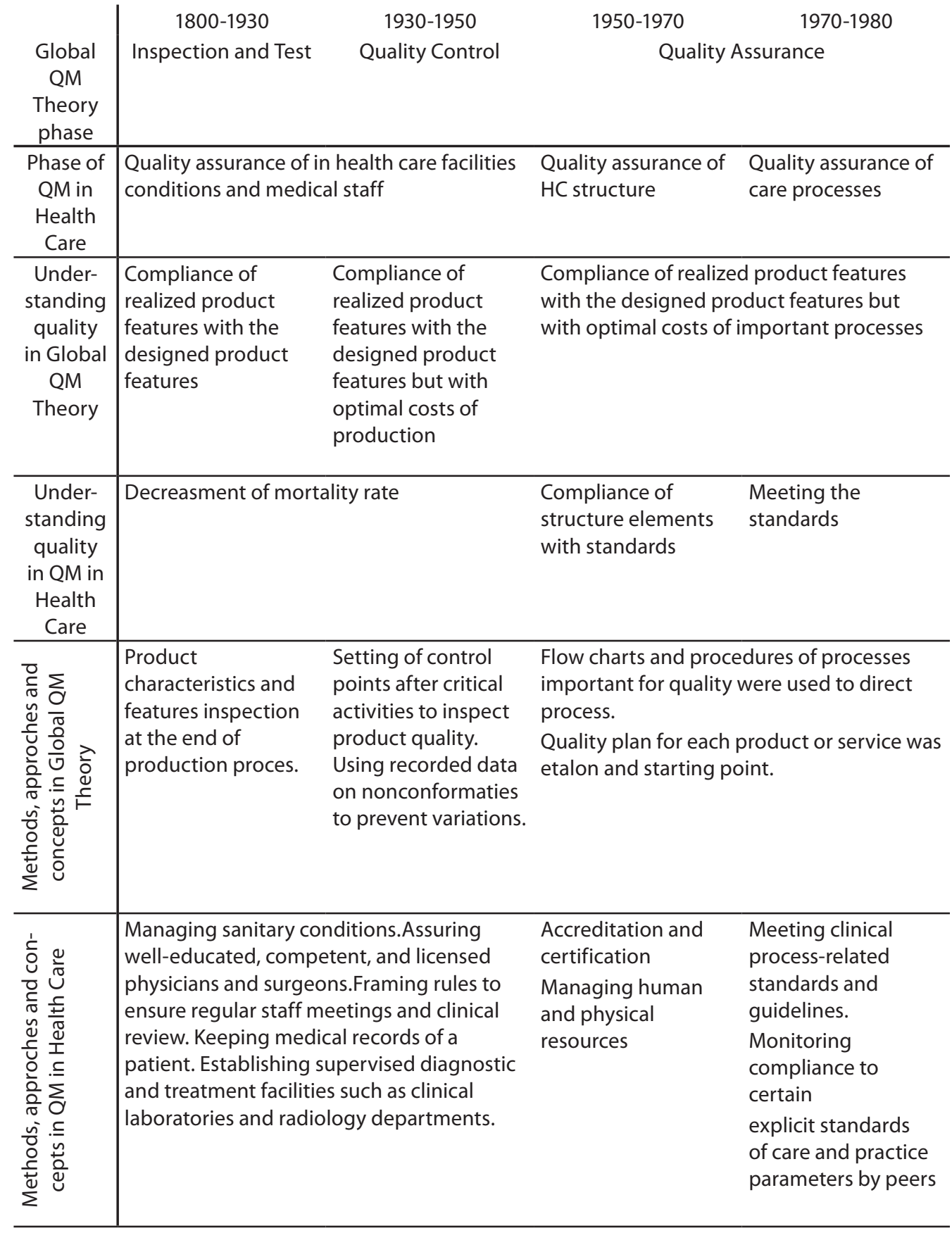


1980-1990

Strategic Quality

Management
$1990-2000$

Total Quality Man-

agement
From 2000 and further

Quality of Life and Sustainbility

Quality improvement

Performance improvement

\begin{tabular}{ll}
\hline Satisfying & Satisfying \\
customers' needs & stakeholders' \\
by products & needs by \\
and services & outcomes which \\
resulted from & are result of \\
optimal process & optimal process \\
conduction & $\begin{array}{l}\text { conduction in } \\
\text { supply chain }\end{array}$ \\
\hline
\end{tabular}

Standardizing care will decrease chance of error and improve control of patient care outcome

Enhancing life expectancy, quality of life, diagnostic

Satisfying current and future needs of every person in society

and treatment options, as well as the efficiency and cost effectiveness of the healthcare system

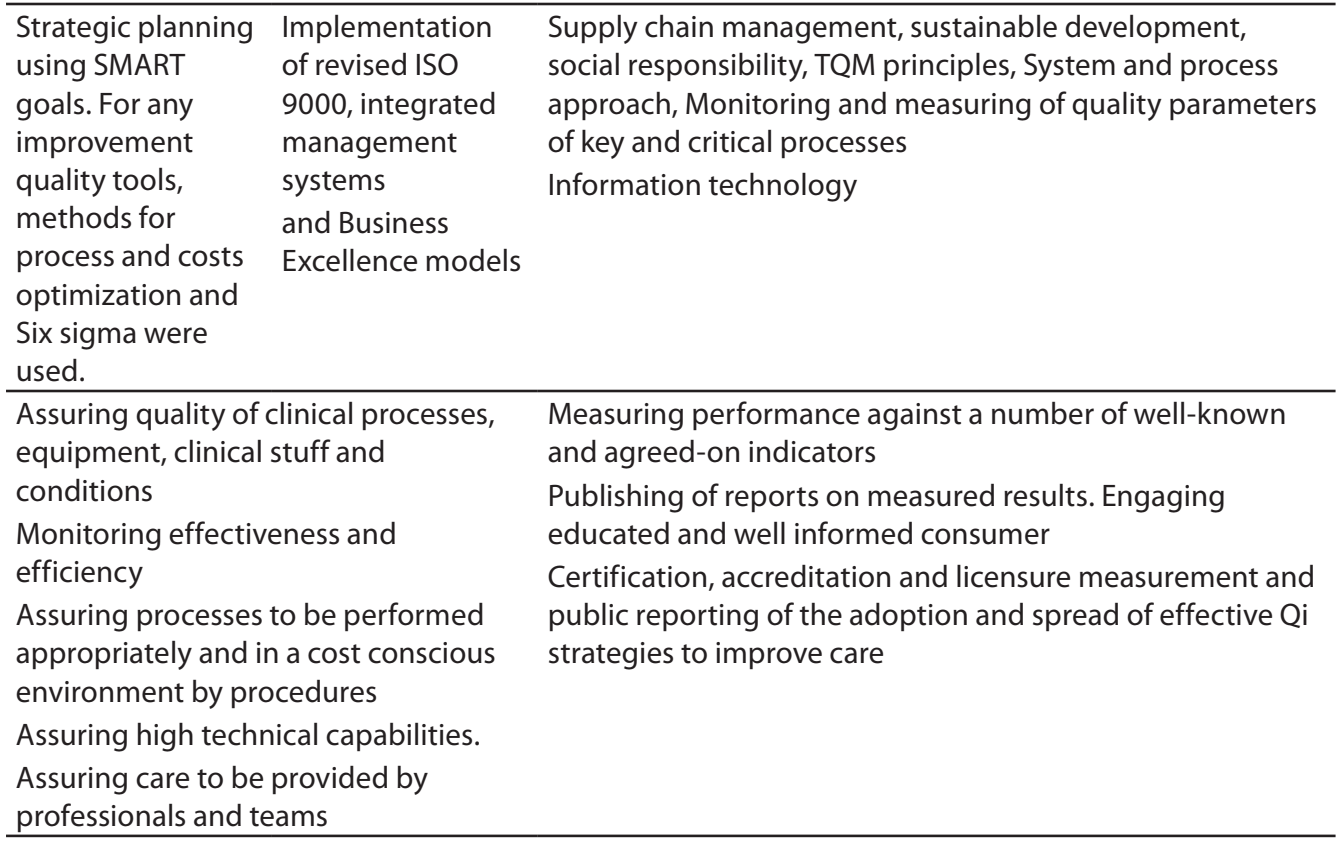


Aleksandra Živaljević, Dragana Trifunović, Biljana Pejović

\begin{tabular}{|c|c|c|c|}
\hline $\begin{array}{l}\text { Missing } \\
\text { in Global } \\
\text { QM } \\
\text { Theory }\end{array}$ & \multicolumn{2}{|c|}{$\begin{array}{l}\text { Managing sanitary conditions, organizing } \\
\text { employees, licencing workers, rules for } \\
\text { conducting reviws }\end{array}$} & $\begin{array}{l}\text { Controling quality of stuff } \\
\text { Monitoring parameters }\end{array}$ \\
\hline 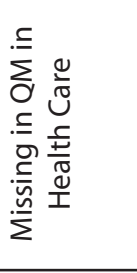 & Identifying errors & $\begin{array}{l}\text { Identifying critical } \\
\text { activities in } \\
\text { processes, setting } \\
\text { control points. Using } \\
\text { recorded data on } \\
\text { errors to prevent } \\
\text { them in future. }\end{array}$ & $\begin{array}{l}\text { Control of supportive processes in } \\
\text { certification and accreditation }\end{array}$ \\
\hline
\end{tabular}

\section{Table's Endnotes}

1 Bergman, B. (1995): "Quality in academic leadership: a contribution to the discussion”, Total Quality Management, 6(5), 487-496.

2 Calvert, P. (2012): "Managing your Library and its Quality: The ISO 9001 Way", The Electronic Library, 30(4), 557-557.

3 Storey, J., et. al. (2006): "Supply chain management: theory, practice and future challenges", International Journal of Operations and Production Management, 26(7), 754-774.

4 Tuazon, D., Corder, G. D., McLellan, B. C. (2013): "Sustainable Development: A Review of Theoretical Contributions", International Journal of Sustainable Future for Human Security, 1(1), 40-48.

5 Acquier, A., Gond, J. P., Pasquero, J. (2011): “Rediscovering Howard R. Bowen's legacy: the unachieved agenda and continuing relevance of social responsibilities of the businessman", Business and Society, 50(4), 607-646.

6 Martínez-Costa, M., et. al. (2009): "ISO 9000/1994, ISO 9001/2000 and TQM: the performance debate revisited", Journal of Operations Management, 27(6), 495-511.

7 Bhuiyan, N., Alam, N. (2005): "An investigation into issues related to the latest version of ISO 9000", Total Quality Management and Business Excellence, 16(2), 199213.

8 Chan, L. H. and 陳蓮雄. (2003): “The effectiveness of ISO 2000 quality system in”, Management, 25(5), 142-145.

9 Al-Assaf, A.F (1994): "Healthcare quality improvement: an overview", Journal of the Royal Medical Services, 1(2), 43-52.

10 Omachonu, V. K., Einspruch, N. G. (2010): "Innovation in healthcare delivery systems: A conceptual framework", The Innovation Journal: The Public Sector Innovation Journal, 15(1), 2-20.

11 Al-Assaf, A. F. (2004): "Introduction and background", 11-28, in: Al-Assaf, A. F., Sheikh, M. (eds.): Quality improvement in primary health care: a practical guide, World Health Organization, Regional Office for the Eastern Mediterranean, Cairo. 


\begin{tabular}{|c|c|c|}
\hline 1 & I & I \\
\hline $\begin{array}{l}\text { Using quality } \\
\text { tools, methods for } \\
\text { process and costs } \\
\text { optimization and } \\
\text { Six sigma for any } \\
\text { improvement }\end{array}$ & $\begin{array}{l}\text { Controlling all } \\
\text { elements of } \\
\text { system, not just } \\
\text { stuff, clinical } \\
\text { processes and } \\
\text { equipment }\end{array}$ & $\begin{array}{l}\text { Controlling outsource organization. Applying TQM } \\
\text { principles on whole organization, not just clinical stuff } \\
\text { and processes. Applying system and process approach. } \\
\text { Monitoring and measuring quality parameters of key } \\
\text { and critical processes, not only of medical methods, } \\
\text { departments or facility. Using IT for quality achievement } \\
\text { and for service delivery }\end{array}$ \\
\hline
\end{tabular}

12 Luce, J. M., Bindman, A. B., Lee, P. R. (1994): "A brief history of health care quality assessment and improvement in the United States", Western Journal of Medicine, 160(3), 263-268.

13 Luce, J. M., Bindman, A. B., Lee, P. R., 263-268.

14 Luce, J. M., Bindman, A. B., Lee, P. R., 263-268.

15 Luce, J. M., Bindman, A. B., Lee, P. R., 263-268.

16 Luce, J. M., Bindman, A. B., Lee, P. R., 263-268.

17 World Health Organization, (2004): Quality improvement in primary health care: a practical guide

18 World Health Organization, (2004).

19 World Health Organization, (2004).

20 World Health Organization, (2004).

21 Binns, G.S. (1991): “The relationship among quality, cost, and market share in hospitals", Topics in health care finance, 18(2), 21-32; Jensen, J. (1991): "Marketing hospital quality", Topics in health care finance, 18(2), 58-66.

22 Al-Assaf, A. F. (2004): "Introduction and background", 11-28, in: Al-Assaf, A. F., Sheikh, M. (eds.): Quality improvement in primary health care: a practical guide, World Health Organization, Regional Office for the Eastern Mediterranean, Cairo.

23 Al-Assaf, A. F., Sheikh, M., 11-28.

24 World Health Organization, (2004).

25 World Health Organization, (2004).

26 Scanlon, D.P., et. al. (2012): “The Aligning forces for Quality initiative: Background and evolution from 2005 to 2012", Am J Manag Care, 18(6), 115-125.

27 Scanlon, D.P., et. al., 115-125.

28 Greenfield, D., Braithwaite, J. (2009): "Developing the evidence base for accreditation of healthcare organisations: a call for transparency and innovation", Quality and Safety in Health Care, 18(3), 162-163.

29 Al-Assaf, A. F. (2001): Health Care Quality. An international perspective, WHO Regional Publication, WHO, New Delhi. 
30 Al-Assaf, A. F. (2001).

31 Luce, J. M., Bindman, A. B., Lee, P. R., 263-268.

32 Evans, J.R. (2014): “A Brief History”, 9-15, in: Joyner, E. (ed.) Quality and Performance Excellence, South-western Cengage Learning, Mason, $\mathrm{OH}$.

33 Al-Assaf, A. F., Sheikh, M., 11-28.

34 Hall, A.D, Fagen, R.E (1968): "Definition of system", 7-21, in: Buckley, W. (ed.): Modern systems research for behavioral scientists. Chicago, Aldine Publishing.

35 Shaw, C. D. (2000): "External quality mechanisms for health care: summary of the ExPeRT project on visitatie, accreditation, EFQM and ISO assessment in European Union countries", International journal for quality in health care, 12(3), 169-175.

36 Shaw, C. D.,169-175.

37 Al-Assaf, A. F., Sheikh, M., 11-28.

38 Heitman, E., Bulger, R. E. (1998): “The healthcare ethics committee in the structural transformation of health care: Administrative and organizational ethics in changing times", HEC Forum, 10(2), 152-176.

39 Institute of Management (IOM) (2001): Crossing the quality chasm: a new health system for the 21st century, National Academy Press, Washington DC.

40 Al-Assaf, A. F., Sheikh, M., 11-28.

41 Scanlon, D.P., et. al. (2012): “The Aligning forces for Quality initiative: Background and evolution from 2005 to 2012", Am J Manag Care, 18(6), 115-125.

42 Sandrick, K. (2003): "Tops in quality. SSM is the first health care system to win the Malcolm Baldrige National Quality Award”, Trustee: The Journal for Hospital Governing Boards, 56(8), 12-6. 


\section{Literature:}

- Acquier, A., Gond, J. P., Pasquero, J. (2011): “Rediscovering Howard R. Bowen’s legacy: the unachieved agenda and continuing relevance of social responsibilities of the businessman", Business and Society, 50(4), 607-646. doi:10.1177/0007650311419251

- Al-Assaf, A.F (1994): "Healthcare quality improvement: an overview", Journal of the Royal Medical Services, 1(2), 43-52.

- Al-Assaf, A. F. (2001): Health Care Quality. An international perspective, WHO Regional Publication, WHO, New Delhi.

- Al-Assaf, A. F. (2004): "Introduction and background", 11-28, in: Al-Assaf, A. F., Sheikh, M. (eds.): Quality improvement in primary health care: a practical guide, World Health Organization, Regional Office for the Eastern Mediterranean, Cairo.

- Alic, M., Rusjan, B. (2010): "Contribution of the ISO 9001 internal audit to business performance", International Journal of Quality and Reliability Management, 27(8), 916-937.

- Amarasingham, R. et. al. (2014): "Implementing Electronic Health Care Predictive Analytics: Considerations and Challenges", Health Affairs, 33(7), 1148-1154.

- Ardianto, Y. T., Natsir, M. (2014): "Hybrid Strategies Study: Total Quality Management Practices and Supply Chain Management as a New Antesenden to Improve the Performance of Manufacturing in East Java", European Journal of Business and Management, 6(30), 1-10.

- Attanasio, O., Oppedisano, V., Vera-Hernández, M. (2014): "Should Cash Transfers Be Conditional? Conditionality, Preventive Care, and Health Outcomes", American Economic Journal: Applied Economics, http://www.homepages.ucl.ac.uk/ uctpamv/ papers/conditionality.pdf (20.12.2014).

- Bergman, B. (1995): "Quality in academic leadership: a contribution to the discussion”, Total Quality Management, 6(5), 487-496.

- Berlin, C. (1994): "Implementation of the total quality management concept within space business", Total Quality Management, 5(4), 123-137.

- Bhuiyan, N., Alam, N. (2005): "An investigation into issues related to the latest version of ISO 9000", Total quality management and business excellence, 16(2), 199-213.

- Binns, G.S. (1991): “The relationship among quality, cost, and market share in hospitals", Topics in health care finance, 18(2), 21-32.

- Bull, M. J. (1997): "Lessons from the past: vision for the future of quality care. Improving Quality", 3-16, in: Maisenheimer, C. G. (ed.): A Guide to Effective Programs, Gaithersburg, Md.: Aspen Publishers, Massachusetts (2nd edition)

- Cabin, W., et. al. (2014): "For-Profit Medicare Home Health Agencies' Costs Appear Higher and Quality Appears Lower Compared To Nonprofit Agencies", Health Affairs, 33(8), 1460-1465.

- Calvert, P. (2012): "Managing your Library and its Quality: The ISO 9001 Way", The Electronic Library, 30(4), 557-557. 
- Chan, L. H. and 陳蓮雄. (2003): “The effectiveness of ISO 2000 quality system in”, Management, 25(5), 142-145.

- Cohen, I. B. (1984): “Florence Nightingale”, Scientific American, 250(3), 128-137.

- Cutler, D. (2014): The Quality Cure: How Focusing on Health Care Quality Can Save Your Life and Lower Spending Too, University of California Press. (Volume 9)

- Douglas, A., Glen, D. (2000): "Integrated management systems in small and medium enterprises”, Total Quality Management, 11, 686-690.

- Drake, R. L. (2014): "A retrospective and prospective look at medical education in the United States: Trends shaping anatomical sciences education", Journal of anatomy, 224(3), 256-260.

- $\quad$ Evans, J.R. (2014): “A Brief History”, 9-15, in: Joyner, E. (ed.) Quality and Performance Excellence, South-western Cengage Learning, Mason, $\mathrm{OH}$.

- Ferlie, E.B., Shortell, S.M. (2001): "Improving the quality of health care in the United Kingdom and the United States: A framework for change”, Milbank Quarterly, 79(2), $281-316$.

- Foltran F, et. al. (2009): "Monitoring the performance of intensive care units using the variable life-adjusted display: a simulation study to explore its applicability and efficiency", Journal of evaluation in clinical practice, 15(3), 506-513.

- George, V. M., Shocksnider, J. (2014): "Leaders: Are You Ready for Change? The Clinical Nurse as Care Coordinator in the New Health Care System", Nursing administration quarterly, 38(1), 78-85.

- Gill, J. (2009): “Quality follows quality: add quality to the business and quality will multiply the profits", The TQM Journal, 21(5), 530-539.

- Greenfield, D., Braithwaite, J. (2009): "Developing the evidence base for accreditation of healthcare organisations: a call for transparency and innovation", Quality and Safety in Health Care, 18(3), 162-163.

- Grint, K., Case, P. (1998): "The violent rhetoric of reengineering: management consultancy on the offensive", J Manag Stud, 35, 557-77.

- Hall, A.D, Fagen, R.E (1968): “Definition of system”, 7-21, in: Buckley, W. (ed.): Modern systems research for behavioral scientists. Chicago, Aldine Publishing.

- Hébert, R. F. (1977): "Edwin Chadwick and the economics of crime", Economic Inquiry, 15(4), 539-550.

- Heitman, E., Bulger, R. E. (1998): “The healthcare ethics committee in the structural transformation of health care: Administrative and organizational ethics in changing times", HEC Forum, 10(2), 152-176.

- Heras-Saizarbitoria, I., Boiral, O. (2013): “ISO 9001 and ISO 14001: Towards a Research Agenda on Management System Standards", International Journal of Management Reviews, 15(1), 47-65.

- Huycke, L.R., All, A.C. (2000): "Quality in health care and ethical principles", Journal of Advanced Nursing, 32(3), 562-571. doi: 10.1046/j.1365-2648.2000.01540.x

- Institute of Management (IOM) (2001): Crossing the quality chasm: a new health system for the 21st century, National Academy Press, Washington DC. 
- Ivanovic, M. D., Majstorovic, V. D. (2006): "Model developed for the assessment of quality management level in manufacturing systems", The TQM Magazine, 18(4), 410-423.

- Jain, D. R., Mishra, V. (2009): “Total Quality Management: An Empirical Study on Employee's Perspective”, 248-260, in: Dhar, S., Dhar, U., Jain, R. K., Parashar S. (eds.): Value Based Management For Organizational Excellence, Indian Society for Training and Development, New Delhi.

- Jang, W., Lin, C. (2008): "An integrated framework for ISO 9000 motivation, depth of ISO implementation and firm performance. The case of Taiwan", Journal of Manufacturing Technology Management, 19, 194-216.

- Jensen, J. (1991): "Marketing hospital quality", Topics in health care finance, 18(2), $58-66$.

- Kreis, S. (1995): "Early experiements in British scientific management: the Health of Munitions Workers' Committee, 1915-1920", Journal of Management History, $1(2), 65-78$.

- $\quad$ Kuei, C. H., Madu, C. N. (2003): "Customer-centric six sigma quality and reliability management”, International Journal of Quality and Reliability Management, 20(8), 954-964.

- Lewis, B. (1999): "Managing service quality" 181-197, in: Dale, B. (Ed.) Managing Quality, Blackwell, Oxford.

- Locock, L. (2003): "Healthcare redesign: meaning, origins and application", Quality and Safety in Health Care, 12(1), 53-57.

- $\quad$ Luce, J. M., Bindman, A. B., Lee, P. R. (1994): "A brief history of health care quality assessment and improvement in the United States", Western Journal of Medicine, 160(3), 263-268.

- Main, D. S., et. al. (2007) "Relationship of processes and structures of care in general surgery to postoperative outcomes: a qualitative analysis", Journal of the American College of Surgeons, 204(6), 1147-1156.

- Martínez-Costa, M., et. al. (2009): "ISO 9000/1994, ISO 9001/2000 and TQM: the performance debate revisited", Journal of Operations Management, 27(6), 495-511.

- Martínez-Lorente, A. R., Martínez-Costa, M. (2004): "ISO 9000 and TQM: substitutes or complementaries?: An empirical study in industrial companies", International Journal of Quality and Reliability Management, 21 (3), 260-276.

- Mersha, T., Sriram, V., Herron, L. (2009): “The impact of TQM implementation in a human service agency", International Journal of Productivity and Quality Management, 4(1), 1-19.

- Mullan, F. (2001): "A founder of quality assessment encounters a troubled system firsthand", Health Affairs, 20(1), 137-141.

- Naumova, N. A., Kharisova, F. I. (2014): "Effective Internal Audit Service Organisation in Health Clinics", Mediterranean Journal of Social Sciences, 5(24), 170-179. 
- Omachonu, V. K., Einspruch, N. G. (2010): "Innovation in healthcare delivery systems: A conceptual framework", The Innovation Journal: The Public Sector Innovation Journal, 15(1), 2-20.

- $\quad$ Parekh, A. K., Kronick, R., Tavenner, M. (2014): “Optimizing health for persons with multiple chronic conditions”, JAMA, 312(12), 1199-1200.

- Porto, G. G. (2001): "Safety by design: Ten lessons from human factors research", Journal of Healthcare Risk Management, 21(3), 43-50.

- $\quad$ Prickett, T. W., Rapley, C. W. (2001): "Quality costing: a study of manufacturing organizations. Part 2: main survey”, Total Quality Management, 12(2), 211-222.

- $\quad$ Raho, L., Mears, P. (1997): "Quality system chaining: The next link in the evolution of quality”, Business Horizons., 40(5), 65-73.

- Salah, S., Carretero, J. A., Rahim, A. (2009): "Six Sigma and Total Quality Management (TQM similarities, differences and relationship", International Journal of Six Sigma and Competitive Advantage, 5(3), 237-250.

- $\quad$ Salimifard, K., Zanjirani, D.M., Keshtkar, L. (2014): "Using simulation to improve hospital resource management”, Megatrend Review, 11(3), 229-238.

- $\quad$ Sandrick, K. (2003): "Tops in quality. SSM is the first health care system to win the Malcolm Baldrige National Quality Award", Trustee: The Journal for Hospital Governing Boards, 56(8), 12-6.

- Scanlon, D.P., et. al. (2012): “The Aligning forces for Quality initiative: Background and evolution from 2005 to 2012", Am J Manag Care, 18(6), 115-125.

- $\quad$ Seth, D., Tripathi, D. (2008): “Impact of Japanese Quality and Maintenance Management Solutions (TQM and TPM) on Business Performance: An Assessment for Indian Manufacturing Industry”, 377-389, in: Mohanty, R.P. (ed.): Quality Management Practices, Excel Books, New Delhi.

- Shaw, C. D. (2000): "External quality mechanisms for health care: summary of the ExPeRT project on visitatie, accreditation, EFQM and ISO assessment in European Union countries", International journal for quality in health care, 12(3), 169-175.

- Storey, J., et. al. (2006): "Supply chain management: theory, practice and future challenges", International Journal of Operations and Production Management, 26(7), 754-774.

- Tuazon, D., Corder, G. D., McLellan, B. C. (2013): "Sustainable Development: A Review of Theoretical Contributions", International Journal of Sustainable Future for Human Security, 1(1), 40-48.

- Turan, A. H., Palvia, P. C. (2014): “Critical information technology issues in Turkish healthcare”, Information and Management, 51(1), 57-68.

- Vouzas, F., Psychogios, A. G. (2007): “Assessing managers' awareness of TQM", The TQM Magazine, 19(1), 62-75.

- Wagner, C., et. al. (2006): "The implementation of quality management systems in hospitals: A comparison between three countries”, BMC Health Services Research, $6(1), 50-61$. 
- Wears, R. L., Hunte, G. S. (2014): “Seeing patient safety 'Like a State”, Safety Science, 67, 50-57. doi:10.1016/j.ssci.2014.02.007

- World Health Organization, (2004): Quality improvement in primary health care: a practical guide. http://www.who.int/iris/handle/10665/119694\#sthash.05trEh30.dpuf (18.11.2014).

- Yang, C. C. (2006): “The impact of human resource management practices on the implementation of total quality management: an empirical study on high-tech firms", The TQM Magazine, 18(2), 162-173.

- Yong, J., Wilkinson, A. (2002): “The long and winding road: The evolution of quality management", Total Quality Management, 13(1), 101-121

- Zhao, X., Yeung, A. C., Lee, T. S. (2004): "Quality management and organizational context in selected service industries of China", Journal of Operations Management, 22(6), 575-587.

- ZZivaljević, A., Mitrović, Ž., Petković, M. (2013): “Conceptual and mathematical model for quality improvement in health care", The Service Industries Journal, 33(5), 516-541. doi:10.1080/02642069.2011.622368

Rad primljen 13. novembra 2015.

Paper received: November $13^{\text {th }}, 2015$

Odobren za štampu 20. januara 2016.

Approved for publication: January $20^{\text {th }}, 2016$ 
Doc. DR Aleksandra Živaljević

Fakultet za poslovne studije, Univerzitet Džon Nezbit, Beograd

Doc. Dr Dragana Trifunović

Fakultet za poslovne studije, Univerzitet Džon Nezbit, Beograd

Ms. Biljana Pejović, asistent

Fakultet za poslovne studije, Univerzitet Džon Nezbit, Beograd

\title{
DVE EVOLUCIJE KVALITETA: INDUSTRIJA VS. ZDRAVSTVO
}

\begin{abstract}
Sažetak
Rad pruža uvid u istorijski razvoj menadžmenta kvalitetom u zdravstvu, kao i rezultate komparativne analize istorijskog razvoja menadžmenta kvaliteta u zdravstvu i istorijskog razvoja naučne discipline menadžmenta kvalitetom. Obe evolucije prikazane su kroz etape razvoja koje karakterišu različiti pristupi menadžmentu kvalitetom i metode koje su dominirale tim etapama. U svom istraživanju autori su se oslonili na već postojeće izvore, publikovane u naučnim i stručnim časopisima, te ga sproveli kroz tri faze: istraživanje razvoja globalne teorije menadžmenta kvalitetom, koja se razvijala prevashodno kroz primenu u industriji, istraživanje razvoja menadžmenta kvalitetom u zdravstvu, a zatim komparativna analiza prikupljenih podataka o obe evolucije. Za potrebe prve i druge faze istraživanja korišćena je EBSCO naučna baza, kako bi se pristupilo naučnim i stručnim časopisima koji sadrže relevantne podatke. Komparativna analiza je pokazala da su između pomenute dve evolucije postojali jazovi koji su i danas prisutni. Dva evolutivna puta iste naučne discipline u dve sfere, dovode do toga da menadžment kvalitetom u industriji beleži daleko bolje rezultate nego u zdravstvu. Stoga su autori identifikovali četiri važne preporuke za unapređenje menadžmenta kvalitetom u zdravstvu.
\end{abstract}

Ključne reči: menadžment kvaliteta, evolucija, zdravstvo, industrija, uporedne analize 